\title{
Investigating the Enactment of Inclusive Education at a University Level: A Call for Literacy Practices in Inclusive Learning
}

\author{
Luluk S. A. Prasetyoningsih ${ }^{1, *}$ Diah R. Widowati ${ }^{2,}$ M. F. Ubaidillah ${ }^{3,}$ \\ Huan Y. Lee ${ }^{4}$ \\ ${ }^{I}$ Department of Indonesian Language Education, Universitas Islam Malang, Indonesia \\ ${ }^{2}$ Department of English Language Education, Universitas Islam Malang, Indonesia \\ ${ }^{3}$ Center for Scientific Publication, Universitas Negeri Malang, Indonesia \\ ${ }^{4}$ School of Education, The University of Queensland, Australia \\ *Corresponding author.Email: luluksap58@unisma.ac.id
}

\begin{abstract}
Empirical evidence on practices of inclusive education has long saturated the literature to date. However, little attention is directed at portraying the enactment of inclusive education from policy-making perspectives during the COVID-19 pandemic. To fill such a void, this paper, situated within an Indonesian higher education context, reports on a case study that attempts to explore (1) gifted student's characteristics in the inclusive education, (2) the student's sustained participation in the program, and (3) the barriers encountered during the inclusive education implementation. Data in this study were generated through in-depth interviews with a single gifted student. The study's findings suggest that the participant experienced well-attained prior learning in the schooling sector in his senior high school and enacted agency in the university's learning through active participation in the teaching assistantship and internship programs for Merdeka Belajar Kampus Merdeka (MBKM) policy implementation. Despite these, undervaluing views from society is also seen in the interview. The study calls for stakeholders to construe gifted students' learning characteristics, accommodate the students' participation, and provide treatment on how society could appreciate such students' academic excellence regardless of their special needs. Future research should also continue this scholarship using ethnography design in different educational settings.
\end{abstract}

Keywords: COVID-19, Gifted student, Higher education, Inclusive education, Literacy.

\section{INTRODUCTION}

As global phenomenon, coronavirus disease (COVID-19) has adversely influenced many aspects in the education sectors such as learning disruption, minimal access for facility, and students' increased debts [4], [48]. While COVID-19 has been extremely distractive for education sectors, educational researchers seem unaware to explore the practice of inclusive education during COVID-19 pandemic. It is evident from empirical evidence that reports the general education enactment during COVID-19 pandemic in many countries in the world [31], [33].

In recent years, studies exploring inclusive education have reached its momentum. It is evident from the presence of extensive literature studies both using empirical data and theoretical perspectives [17], [20], [31], [32], [45]. The existing studies on inclusive education mainly discuss the ways teachers treat special need students with appropriate teaching methodologies in the class. However, efforts to equip better learning circumstances for gifted student are not without problems. For example, in an African schooling context, particularly in Zimbabwe, students are found facing multifaceted dilemmas such as negative interaction with teachers, parental disparities, and societal problems [49]. In another study by [12], it is observed that gifted student encountered no parental involvement in schooling activities and received minimal support from classmates. It is also found that inclusive education and gifted student in many countries are not well prepared yet [24], [43].

Theoretically, inclusive education is set up to facilitate gifted student in their learning with appropriate teaching methodologies in the schools. 
To some extent, inclusive education may be in different forms [15]. Apparently, education for gifted student provides inclusive pedagogies that enable students to engage and interact with their peers collaboratively in the classroom. Despite this, there is an uncommon understanding of what matters in inclusive pedagogies among university researchers recently [46]. Anchored by this discrepancy, there should be an effort to investigate the practice of inclusive education at the university level, particularly in a developing country such as Indonesia during the pandemic.

Empirical evidence has indicated that inclusive education worldwide is portrayed less prepared for gifted students. It is also similar to the condition of gifted student in Indonesia where many complexities are constantly encountered [41]. Specifically, [14] unraveled that pre-service teachers' attitudes toward inclusive education in the province of Yogyakarta, Indonesia is seen as ordinary, showing that they do not have special attention toward gifted student. Interestingly, in a systematic review study of inclusive education enactment in the Indonesian context, Kristiana and [29] summarized that such a practice in Indonesia is categorized as good. This finding does not correspond to previous studies exploring inclusive education in schooling and tertiary education levels.

Until recently, very little attention has been directed to portray the enactment of inclusive education in Indonesian higher education contexts [9]. It is evident that previous research was done in the contexts of pre-school and primary schooling sectors. In particular, the dearth of inclusive education studies in the Indonesian university context can be understood from the evidence that many scholars focus on inclusive education for young learners [3]. Therefore, to fill this gap, the present study is situated at an Indonesian university level and investigates the enactment of inclusive education within the curriculum reform.

The curriculum is reformed to organize students, especially in tertiary levels, to face rapid changes in technology, workplaces, and sociocultural lives, so that students' capability must be upgraded to adapt and meet the need such development. The curriculum Merdeka Belajar Kampus Merdeka (MBKM), a tagline for freedom to learn and freedom campus, enacted by the Indonesian Ministry of Education and Culture, is a solution for the development of education in Industry Revolution 4.0, which involves three core aspects, namely human literation, technology literation, and data literation [52], and it is related to the dynamics of assessment [13]. This curriculum enables students to sharpen their abilities, skills, and talents without any restraint. [30]

While research studies on the implementation of MBKM [6], [16], [21],[28], [39]; [40], [47] have been mushrooming, little is known about the enactment of MBKM in the context of inclusive education in a university setting. Therefore, the present study probes into the learning characteristics of a gifted-talented student in the inclusive education, gifted-talented student's sustained participation in inclusive education, and the barriers encountered by a gifted-talented student during participation in inclusive education.

\section{METHODS}

\subsection{Design and Research Participant}

The present study was carried out using an indepth interview with a single gifted-talented student (henceforth, participant) situated in a faculty of teacher training and education of a private university based in Malang, Indonesia. The university enacts Merdeka Belajar Kampus Merdeka (MBKM), a tagline for freedom to learn and freedom campus, curriculum reform as mandated by the Indonesian Ministry of Education (MoE). This study, recruiting a single participant (male, aged 20 years old), aimed to inquire about his participation in the inclusive education enactment. It is because he was the only gifted-talented student who join more than two MBKM programs initiated by MoE. For ethical considerations, we first sent a consent form to the participant in order to give freedom if he was willing to participate in the study. Besides, to ensure the anonymity, his name was made pseudonym as AA.

\subsection{Data Collection and Analysis}

The present research employed semi-structured interview, in which the questions were constructed by the researchers by considering the characteristics of the participant. The interview sessions were done using participant's national language and recorded using a smartphone recording tool. These interviews were done multiple times until we found salient voices from participant's shared perspectives. In analyzing the data, we conducted repeated readings on the interview transcripts to obtain a global understanding of the data. In line with that, we categorized each similar interview response into an 
emerging theme. Three common themes were revealed in this process: gifted student's learning characteristics, student sustained participation in inclusive education, and barriers encountered during the inclusive education enactment. The results of the interview were transcribed before it was used as the data to be discussed.

\section{RESULTS AND DISCUSSIONS}

Findings from the study are detailed into three themes: learning characteristics, student's sustained participation, and barriers encountered during participation in the inclusive education.

\subsection{Learning characteristics in the inclusive education during COVID-19 Pandemic}

The first themed finding seen from the interview is the participant's learning characteristics. In this study, the gifted-talented student who participated in the MBKM program at the university was found engaged fully in the learning process. The Grade Point Average (GPA) of this student is 3.96 out of 4.00 , which is pretty high. Firstly, our interview portrays the participant's prior schooling. He shared that:

\section{Excerpt 1}

I chose a language program in my senior high school. At that time, I participated in a lot of poetry reading and debating competitions. I also read many books. On top of that, I have been accustomed to writing short pieces of articles on my school wall magazine.

The interview depicts AA's prior schooling experience as an active actor by showing his agency and/or initiative to delve into the school participation. The participant attempted to socialize into a community of practice with external experiences and circumstance in the forms of competition to gain knowledge and wider experience [49]. AA, in the interview, is seen to set his learning goals during his study at the school. AA also shared his response in the interview:

\section{Excerpt 2}

I always set a target in my learning. I also enjoy the learning activities with the target I have set previously. I feel that when I do it continuously, then, I can reach the targeted goals. I also manage my time well. This is important since time management in learning can provide opportunities for me to set an effective learning schedule.

The response shows that the participating student has a high initiative in working. In line with this finding, previous study unpacks that schooling environment is a crucial site for school-aged children to showcase their perspectives, enact peer interactions, and teacher relationship [38]. The results also echo previous research by [37] who reveal that positive relationship among students and teachers and the school environment allows for positive emotions among them, and might support students' learning activity [5], therefore many countries have been widening learning access for inclusive education [44], [8], [36]. In other words, the supportive environment can help students to reduce barriers to social interaction.

\subsection{Student's sustained participation in the inclusive education}

Our second themed-finding from the interview showcases participant's sustained participation in the inclusive education program. The participant of this study is involved in MBKM program for teaching assistantship for one semester. Including AA, he was selected to participate as the representation from inclusive education institution of a private university based in Malang, East Java, Indonesia. In the interview with us, AA narrated that:

\section{Excerpt 3}

I was selected to participate in a teaching assistantship for elementary school teachers in Malang. My responsibility is to share knowledge on technology use in the classroom such as Zoom and Google meet. Many teachers at the school were unfamiliar with such technological tools for learning. I also campaigned for literacy in the school. It is about knowing literacy for learning and literacy for life.

In line with the study's findings, [22] argue that gifted student' participation in the inclusive education is rarely documented. It is use to the fact that most of their presences in the schooling activities are seen less attractive. In the context of higher education, according to [10], such phenomenon also occurs. Interestingly, in our study, AA showcases his active participation in the inclusive education program such as teaching assistantship. In response to the previous studies [11], [24], [25], [34], the study's finding does not correspond. 
In the next interview, AA also shared that he was involved in an internship program:

\section{Excerpt 4}

I also joined an internship program as a journalist in Malang area. It was very interesting and challenging as well since I was targeted to produce two article reports in a week. Through the program, I am aware of the important of writing skill and reporting every event as headlines on newspaper.

Aside from participating in a teaching assistantship program AA also actively participated in an internship program in the following months. This shows the fact in the study that AA's agency in learning is attained and well-performed. Previous studies negatively undermined gifted student' learning performance [7], [19], [50], and this might contribute to students' underachievement [42].

Therefore, teachers and parents through inclusive education are required to recognize the giftedtalented students by providing them with various opportunities to expand their talents. Gaining familiarity with gifted children, recognizing the manifold materializations of one's extraordinary capability and the developmental nature of talent development, connecting recognition to involvement, employing multiple measurements, conjoining the assessment of motivation, contemplating social and emotional needs, and controlling the recommended interventions might help gifted-talented students to optimize their potentials [36]. One of crucial aspects is encouraging the gifted-talented students' potential is to deal with the future career [26], [18], [23]. Hence, knowing gifted-talented students' skills in learning is essential to help them develop effectively.

\subsection{Barriers encountered during participation in inclusive education}

In our interview with AA, some obstacles during his active participation in the inclusive education programs in the pandemic crisis are captured. He shared in the interview that:

\section{Excerpt 5}

When I participated in the student exchange program, it was done online and hampered me from knowing culturally diverse societies well. Yeah..... online student exchange was good actually but of course it also creates an uninteresting experience since I cannot have a direct contact with societies. Yes, because it is done online.

In the other interview, AA contended that:

\section{Excerpt 6:}

At first, I was undervalued just because of my special need condition during my participation in the inclusive education. It was annoying but I had to showcase my skills and performance amidst such humiliating experiences.

Our study documents AA's multifaceted barriers during his participation in the inclusive education program. As he mentioned in the interview, the online student exchange was not much contributive to his learning experience. Although previous research has yielded efforts made by government in innovating student exchange during COVID-19 pandemic [51], such an endeavor seems to not happen with the Indonesian government. The findings of this study illustrate how COVID-19 has been destructive for educational domains. What also maters in our study are that AA experienced negative valuing from other participants due to his impaired condition. Previous studies also unravel that, in general, gifted student are consistently seen as 'different' among other normal people in their environment [1], [2], [27].

The present study has sought to investigate, using an interview study, a single gifted student's learning characteristics, participation, and complexities encountered during inclusive education program enactment. The study is situated in an Indonesian higher education context since previous studies mainly focus on primary schooling sector. The findings shed light that our participant's prior schooling has been very contributive to his present university learning engagement. Also, his sustained participation in the inclusive education program showcases that student with impairment can still become an active actor in learning during the pandemic. Although true, as a general consequence, AA still faced challenges from the surrounding with regard to his status as a special need student.

\section{CONCLUSION}

To conclude, the present study portrayed three themed-findings from the interview sessions with the participant. First, the participant's prior schooling is a key determiner when enacting his agency in the university-level. By experiencing well-rounded and holistic learning model in his previous senior high 
school, the participant became aware of his role as a university student, despite his impairment. Second, active participation in the inclusive education programs also led to favourable/positive outcomes. It is seen from his sustained participation in the teaching assistantship and internship programs. Although the participant's participation in the community of practice is commendable, the interview unpacks an inherent discriminatory attitude and humiliating treatment by the society towards his participation. The study calls for stakeholders to better understand gifted students' learning characteristics, accommodate the students' participation, and create awareness among the society to appreciate such students' academic excellence regardless of their impairment status. Future research may also continue this scholarship using ethnography research design, for example, by studying students in public secondary schooling settings or Islamic schools (e.g., madrasah).

\section{AUTHORS' CONTRIBUTIONS}

All authors conceived and designed this study. All authors contributed to the process of revising the manuscript, and at the end all author have approved the final version of this manuscript.

\section{ACKNOWLEDGMENTS}

We are grateful to the Institute of Research and Community Services (LPPM), Universitas Islam Malang, for funding this study through HIBAH INSTITUSI UNISMA (HI-ma) with contract number: 014/G164/U.LPPM/K/B.07/I/2021. Our thanks are also addressed to Lisa Ramadhani at Tim Percepatan Publikasi, Universitas Negeri Malang, for her corrective feedback on this paper.

\section{REFERENCES}

[1] M. M. Ali, R. Mustapha, \& Z. M. Jelas. An Empirical Study on Teachers' Perceptions towards Inclusive Education in Malaysia, International journal of special education, 2006, pp. 36-44.

[2] A. Amka. Social participation of deaf students within inclusive higher education, International Journal of Innovation. Creativity and Change, 2020, pp. 25-40.

[3] E. Andriana, \& D. Evans. Listening to the voices of students on inclusive education: Responses from principals and teachers in
Indonesia. International Journal of Educational Research, 2020, pp. 101644.

[4] M. I. Bellini, L. Pengel, L. Potena, L. Segantini, \& ESOT COVID-19 Working Group. COVID-19 and education: restructuring after the pandemic. Transplant International, 2021, pp. 220-223.

[5] Y. Anggraini, S. Patmanthara., \& P. Purnomo. Pengaruh Lingkungan Belajar Dan Disiplin Belajar Terhadap Hasil Belajar Kompetensi Keahlian Elektronika Industri Di Sekolah Menengah Kejuruan [The Effect of Learning Environment and Learning Discipline on Learning Outcomes of Industrial Electronics Expertise Competencies in Vocational High Schools]. Jurnal Pendidikan: Teori, Penelitian, Dan Pengembangan, 2017, pp. 1650-1655.

[6] M. Anis., \& C. Anwar. Self-organized learning environment teaching strategy for ELT in Merdeka Belajar concept for high school students in Indonesia. JEES (Journal of English Educators Society), 2020, pp. 199-204.

[7] G. I. Bayram., M. S. Corlu., E. Aydın., D. Ortaçtepe., \& B. Alapala. An exploratory study of visually impaired students' perceptions of inclusive mathematics education. British Journal of Visual Impairment, 2015, pp. 212219.

[8] E. C. Bouck., R. Satsangi., \& S. Flanagan. Focus on inclusive education: evaluating apps for students with disabilities: supporting academic access and success: Bradley Witzel, editor. Childhood Education, 2016, pp. 324328.

[9] E. Brewis. Fair access to higher education and discourses of development: a policy analysis from Indonesia. Compare: A Journal of Comparative and International Education, 2019, pp. 453-470.

[10] T. Bualar. Barriers to inclusive higher education in Thailand: voices of blind students. Asia Pacific Education Review, 2018, pp. 469-477.

[11] S. Calvo., L. Celini., A. Morales., G. M. J. Martínez., \& P. Núñez-Cacho Utrilla. Academic literacy and student diversity: Evaluating a curriculum-integrated inclusive practice intervention in the United Kingdom. Sustainability, 2020, pp. 1155. 
[12] N. Dash. Problems and challenges of inclusive education for students with special needs. Online International Interdisciplinary Research Journal, 2018, pp. 155-162.

[13] A. D. Utami. Curriculum Reform in the decentralization of education in Indonesia: effect on students' achievements, Jurnal Cakrawala Pendidikan. 2021, pp. 158-169.

[14] R. Maulida., N. I. Atika., \& N. Kawai, N. The Pre-Service Teachers' Attitudes Towards Inclusive Education: An Empirical Study in Yogyakarta City, Indonesia. Discourse and Communication for Sustainable Education, 2020, 65-73.

[15] L. Florian. What counts as evidence of inclusive education?, European Journal of Special Needs Education, 2014, pp. 286-294.

[16] T. M. Fuadi., \& D. Aswita. Merdeka Belajar Kampus Merdeka (MBKM): Bagaimana Penerapan dan Kedala Yang Dihadapi oleh Perguruan Tinggi Swasta di Aceh. Jurnal Dedikasi Pendidikan [Freedom to Lean, Freedom Campus: How to Apply and Constraints Faced by Private Universities in Aceh. Journal of Educational Dedication], 2021, pp. 603-614.

[17] J. Gallo-Fox., \& L. Stegeman. Coteaching in early childhood clinical field experiences: a cross-case study of learning affordances. Teaching Education, 2020, pp. 298-322.

[18] M. J. Greene. Helping build lives: Career and life development of gifted and talented students. Professional School Counseling, 2006, pp. 2156759X0601001S05.

[19] I. Hamburg., \& G. Lütgen. Digital divide, digital inclusion and inclusive education. Advances in Social Sciences Research Journal, 2019.

[20] M. Holmqvist., \& B. Lelinge. Teachers' collaborative professional development for inclusive education. European Journal of Special Needs Education, 2021, pp. 819-833.

[21] S. Hudaya., \& A. Supriyanto. Pendidikan humanistic holistic sebagai arah konsep pendidikan merdeka belajar di Indonesia. Seminar Nasional Arah Manajemen Sekolah
Pada Masa Dan Pasca Pandemi Covid-19 [Holistic humanistic education as the direction of the concept of independent education in learning in Indonesia. National Seminar on School Management Directions During and After the Covid-19 Pandemic], 2020.

[22] C. Hughes., J. C. Cosgriff., M. Agran., \& B. H. Washington. Student self-determination: A preliminary investigation of the role of participation in inclusive settings. Education and Training in Autism and Developmental Disabilities, 2013, pp. 3-17.

[23] J. Y. Jung. The career development of gifted students. In International handbook of career guidance, 2019, pp. 325-342.

[24] R. Kamaeva., T. Kvasnikova., M. Egorova., \& L. Kashapova. Problems of teaching students with special needs. Opcion, 35 (Special Issue 23), 2019, pp. 563-580.

[25] V. Z, Kantor, Inclusive educational process in the university: theoretical and experimental model of the psychological readiness of teachers, Education and Science 23(3), 2021, pp. 156-182.

[26] B. A. Kerr. Career education strategies for the gifted. Journal of Career Education, 1981, pp. 318-324.

[27] A. K. Koenen., E. Vervoort., G. Kelchtermans., K. Verschueren., \& J. L. Spilt. Teachers' daily negative emotions in interactions with individual students in special education. Journal of Emotional and Behavioral Disorders, 2019, pp. 37-51.

[28] K. Krishnapatria. Merdeka Belajar-Kampus Merdeka (MBKM) Curriculum in English Studies Program: Challenges and Opportunities, ELT in Focus, 2021, pp. 12-19.

[29] I. F. Kristiana., \& W. Hendriani. Teaching efficacy in Inclusive Education (IE) in Indonesia and other Asia, developing countries: A systematic review. Journal of Education and Learning (EduLearn), 2018, pp. 166-171.

[30] R. S. Kusumaryono, R. S. Merdeka Belajar (Freedom to Lean). Kemdikbud, 2020.

[31] G. Marinoni. Consequences of COVID-19 on Future Society: Some Reflections from the 
Higher Education Sector, Inter Faculty 10, 2020, pp. $165-173$.

[32] J. Ogden., S. Avenell., \& G. Ellis. Negotiating control: patients' experiences of unsuccessful weight-loss surgery. Psychology \& Health, 2011, pp. 949-964.

[33] Y. Ming., \& P. Peggy. Prevención de la enfermedad por coronavirus (COVID-19): educación en el aula virtual para la higiene de las manos. La formación de enfermeras en la práctica, 2020, pp. 02782.

[34] A. Paseka., \& S. Schwab. Parents' attitudes towards inclusive education and their perceptions of inclusive teaching practices and resources. European Journal of Special Needs Education, 2020, pp. 254-272.

[35] PSLB, DIT. Pendidikan Khusus dan Pendidikan Layanan Khusus [Special Education and Special Service Education], 2012.

[36] S. I. Pfeiffer. Identifying gifted and talented students: Recurring issues and promising solutions. Journal of Applied School Psychology, 2002, pp. 31-50.

[37] H. P. Phan., \& B. H. Ngu. Schooling experience and academic performance of Taiwanese students: the importance of psychosocial effects, positive emotions, levels of best practice, and personal well-being. Social Psychology of Education, 2020, pp. 1073-1101.

[38] A. Potts., N. Maadad., \& M. Yu. "My friends are there": Constructions of schooling of children of Filipino immigrants in South Australia. Cogent Education, 2017, pp. 1412036.

[39] B. K. Prahani., U. A. Deta., M. Yasir., S. Astutik., P. Pandiangan., S. Mahtari., \& H. Mubarok. The Concept of" Kampus Merdeka" in Accordance with Freire's Critical Pedagogy. Studies in Philosophy of Science and Education, 2020, pp. 21-37.

[40] E. Purwanti. Preparing the Implementation of Merdeka Belajar-Kampus Merdeka Policy in Higher Education Institutions. 4th International Conference on Sustainable Innovation 2020Social, Humanity, and Education (ICoSIHESS 2020). Atlantis Press, 2021.
[41] S. V. N. Rante., H. Wijaya., \& H. Tulak. Far from Expectation: A Systematic Literature Review of Inclusive Education in Indonesia, 2020.

[42] S. M. Reis., \& D. B. McCoach. Underachievement in gifted and talented students with special needs. Exceptionality, 2002, 113-125.

[43] C. Ringwalt., S. T. Ennett., A. Vincus., \& A. Simons-Rudolph. Students' Special Needs and Problems as Reasons for the Adaptation of Substance Abuse Prevention Curricula in the Nation's Middle Schools. Prevention Science, 2004, pp. 197-206.

[44] R. Rose., J. Narayan., S. Matam., \& P. Reddy Sambram. A Comparison of Provision and Access to Inclusive Education for Children with Disabilities in a Metropolitan City and a Rural District in Telangana State, India. Education Sciences, 2021, pp. 111.

[45] K. Sheehy., Budiyanto, H. Kaye., \& K. Rofiah. Indonesian teachers' epistemological beliefs and inclusive education. Journal of Intellectual Disabilities, 2019, pp. 39-56.

[46] L. Stentiford., \& G. Koutsouris. What are inclusive pedagogies in higher education? A systematic scoping review. Studies in Higher Education, 2021, pp. 2245-2261.

[47] S. Sudaryanto., W. Widayati., \& R. Amalia. Konsep Merdeka Belajar-Kampus Merdeka dan Aplikasinya dalam Pendidikan Bahasa (dan Sastra) Indonesia. Kode [The Concept of Independent Learning-Independent Campus and Its Application in Indonesian Language (and Literature) Education. Code: Language Journal, 2020.], Jurnal Bahasa, 2020.

[48] L. Sun., Y. Tang., \& W. Zuo. Coronavirus pushes education online. Nature Materials, 2020, pp. 687-687.

[49] M. C. Tawodzera., \& M. Themane. Schooling experiences of children left behind in Zimbabwe by emigrating parents: Implications for inclusive education. South African Journal of Education, 39 (Supplement 1), 2019, pp. s1s13.

[50] D. M. Tordoff., S. G. Haley., A. Shook., A. Kantor., J. M. Crouch., \& K. Ahrens. "Talk 
about Bodies": Recommendations for Using Transgender-Inclusive Language in Sex Education Curricula. Sex Roles, 2021, pp. 52165.

[51] J. M. Unger., A. Bhattarai., B. Maisch., J. M. Luetz., \& J. Obuhuma. Fostering innovation and intercultural exchange during a global pandemic: Lessons learned from a virtual design thinking challenge in Nepal. In COVID19: Paving the Way for a More Sustainable World, 2021, pp. 185-209.

[52] M. Yamin., \& S. Syahrir. Pembangunan pendidikan merdeka belajar (telaah metode pembelajaran) [Development of independent learning education (study of learning methods)], Jurnal Ilmiah Mandala Education, 2020. 